\title{
Class and memory activism
}

\section{Till Hilmar, till.hilmar@uni-bremen.de}

To be Published in: Wüstenberg, Jenny; Gutman, Yifat (eds.): Handbook of Memory Activism, New York: Routledge 2022.

\begin{abstract}
In this chapter, I call on memory scholars and activists to revisit the relationship between class and memory. Class, operating through the unequal distribution of both material and symbolic resources, has an inconspicuous, hidden, and tacit quality to it. Thinking through the contradictions posed by class, memory activists fighting for economic and racial justice can give voice to lived experiences of dispossession and bring structures of exploitation to light. The concept of moral economy, I suggest, provides a particularly rich theoretical and empirical repertoire to do so. The chapter identifies potential avenues for research on class and memory activism in four areas in which class is variously institutionalized in society: Generation, milieu, ethnicity and gender.
\end{abstract}

Keywords: inequality, moral economy, generation, milieu, race, gender

Even if the topics of class and social milieu were central to the work of Maurice Halbwachs, memory scholars have, puzzlingly, by and large failed to pick up this thread. As Bin Xu notes, "class" does not appear in the index of a range of seminal scholarly introductions to collective memory $(2019,154)$. However, there are numerous fruitful ways to unveil this link from the perspective of memory activism. The aim of this review is necessary explorative; the goal is to weave existing threads together and to identify potential avenues for research on memory activism and class.

Typically, class is conceptualized, in the Marxist tradition, as the societal antagonism emerging from the unequal distribution of ownership of the means of production, or, in a Weberian perspective, as individuals' systematically varying life chances as determined by education, skills, professional status and income. Class always operates through the unequal distribution of both material and symbolic resources. Class does not make itself apparent, it has an inconspicuous, hidden, and tacit quality to it. This is partly due to the nature of the sentiments that typically accompany the everyday experience of class inequality, in particular, 
moral emotions like shame, inadequacy, jealousy, or arrogance (Sayer 2005, 143-168), as they color interpersonal relations, often in ways that complicate communication. A tension between silence and articulation thus undergirds the ways in which class becomes an object of representation - operating within the parameters of this force-field, memory activists fighting for economic and racial justice can give voice to lived experiences of dispossession and bring structures of exploitation to light.

Historically, social movements have struggled for social and legal protection against the detrimental ramifications of unfettered markets and for the dignity of work. These struggles have only enabled the emergence of welfare institutions, institutions that grant particular groups in society access to economic benefits and protection against risk. Paradoxically perhaps, material fights for redistribution have thus also allowed for stable social roles and identities to form: Welfare arrangements ease material antagonisms by channeling conflict, thereby also fostering a set of durable, collective economic expectations over time. They sustain a memory of their own design. As Gøsta Esping-Anderson (1990) has famously demonstrated in his typology of liberal, social-democratic, and conservative welfare regimes, particular social policy principles and their applications are rooted in inherited ideologies and cultural traditions.

\section{A moral economy sparks memory activism}

This relative stability, however, can be challenged in moments of crisis and social conflict. During such episodes, the power of customary norms underneath welfare institutions - and with it, the transformative power of social memory activism - is laid bare. Scholarship on “moral economy" (Scott 1976, Thompson 1963, Polanyi 2001), situated at the intersection of social history, anthropology and sociology, has driven this point home. Broadly, the concept refers to popular beliefs about legitimate forms of reciprocal exchange in market society. In his account of the English bread riots in the early 18th century, E.P. Thompson famously 
observed how popular discontent with the liberalization of food markets was rooted in a sense of justice nourished by what he called an "older moral economy", a subsistence regime that "taught the immorality of any unfair method of forcing up the price of provisions by profiteering upon the necessities of the people" (Thompson 1963, 63). For Thompson, the collective sentiments generated by a perceived breach in these norms could explain why some instances of deprivation and hunger sparked popular unrest, while others did not. It was the sense that a social contact was violated, and that justice had to be restored, that triggered collective action.

As Arnold (2001) argues, Thompson's depiction of the mechanism that translates objective economic deprivation into grievances is, in fact, rooted in an eventful memory logic, in an insight into the power of collective references to the past: It is the notion that a social contract is violated or broken - "a consensus about what distinguishes legitimate from illegitimate practices $(\ldots)$ rooted in the past" (ibid., 86) that inspires action. A sense of economic victimhood can only ever be generated from ruptures that are meaningful in a given historical and cultural context, in the manner of an idiomatic vocabulary of a collective economic trauma. The mechanism played a critical role, for instance, in the demise of statesocialism in the 20th century. Workers' resistance to the Communist regime in 1980s East Germany and Hungary was sparked by the sense that the political leadership had abandoned its specific promise to value workers - both as subjects, and as productive members of society -, on the shop floor (Bartha 2013).

We can thus identify a particularly powerful articulation of the class-memory link in moments when collective norms are perceived to have been violated. The French Yellow Vest protests first emerging in 2018 serve as a contemporary example: The popular outrage was initially sparked by rising gas prices, but it was nourished by a widely held perception that the government failed to live up to the promise of securing a middle-class way of life. Moral economic contentions revolve around the idea that a sacralized good has been "corrupted" - 
oftentimes, collectively esteemed goods are at the center of these struggles, such as oil in Ecuador (Lyall 2018) or Russia. The notion that one (and one's in-group, or one's national community) is deserving of particular material or symbolic resources is derived from narratives about the past, from an understanding of how legitimate constellations of redistribution came about, and from a certain degree of sacralization of the struggles one had to master in order to attain a particular status position in society.

Activists pursuing an emancipatory idea of economic justice similarly make use of shared images of the past. Examples can be found in the history of the labor movement of the 19th and 20th century (Berger 2017, see also Berger this volume). Labor activists assembled in trade unions, parties, and cooperatives (as well as engaged in more loosely organized forms of protest, such as food riots) to fight material deprivation and exploitation. At the same time, they struggled to attain respectability by imagining normative models of communal life, combining existing norms with newly desired forms of sociability. In this way, labor activists in the Western world linked the model of a (predominantly male) industrial laborer to older Catholic ideas of ethical personhood; in the Global South, a variety of community models, often rooted in agricultural and kindship traditions, were mobilized in the fight against the destructive forces of capitalism and colonialism. These forms of resistance were never just backward-looking, but instead transformative, hopeful, and oriented towards the future. In fact, it is possible to identify at least three overlapping temporalities in fights against dispossession: The sense of a loss of a past order; the sense of broken promises or blocked economic opportunities weighing on the present; and the sense that alternative, future trajectories are available.

Still, in the following, I suggest to take one step back from the tangible outcomes of collective discontent and mobilization and ask: If, in class conflicts, material and symbolic claims are negotiated by mobilizing the past, then how is this tension embedded in various 
institutional arrangements? I explore this question with perspectives from four relevant areas: generation, milieu, ethnicity and gender.

\section{Generation and milieu}

Generational frameworks can reveal shared economic orientations and justice ideologies.

Scholarship on the economic dimension of nostalgia, understood as longing for the past as a time of imagined job stability and social cohesion, has much to contribute, as it systematically explores the emergence, persistence and recalibration of particular ideas about valued ways of life (Todorova and Gille 2010).

There are generation-specific ways of coping with economic crises. Labor market shocks such as those triggered by the global COVID-19 pandemic of 2020 cause unemployment and job insecurity, forcing people to find ways to cope both individually and collectively. People do so by actively mobilizing past material and symbolic resources. For graduating cohorts, labor market shocks can have long-term effects on social mobility, affecting pay levels and the likelihood of job loss years after the initial event. But there is also a collective sense of temporality involved. The economic rupture of the Financial Crisis of 2008, for instance, was variously narrated as a moral injury (Alexander 2018). Case studies from Greece reveal how citizens apprehended the crisis by linking it to earlier experiences of economic deprivation, such as the famine that hit the Greek islands in the middle of the 20th century (Knight 2012). The memory of the post-Communist transformations after 1989 is another case in point. The transformation was a generational rupture, revealing that social mobility itself is not just an economic datum, but a source and an object of memory. David Ost's (2005) research suggests that the generation suffering from the neoliberal turn in post1989 Poland recoded its memory of the late-socialist trade union movement Solidarity in the spirit of a triumph of social Darwinism. For China, Bin Xu (2019) shows how the so-called "Sent-Down-Youth" generation, despite very different class outcomes, share a political 
habitus that structures their interpretation of the state violence that had been instituted against them.

Generational frameworks also highlight the implications of the distribution of wealth in society. Piketty's analysis $(2014,476,515)$ puts the promises of this link in plain sight. Inheritance plays a key role in the unequal distribution of wealth today, but its macroeconomic significance has shifted profoundly over the course of the 20th century, having dramatically increased since the 1970s in North America and Western Europe. The postwar generations in this part of the world experienced a historically exceptional situation in which the fruits of one's labor could guarantee social upward mobility irrespective of inherited fortunes, while those growing up in the 1980s and 1990s encountered a very different world in which the significance of wealth was well on its way to return to levels not seen since the 19th century. The contestation of wealth inequality, as much as its justification, always relies on interpretations of the past. Crucially, in this way, memory itself can be part of the very economic mechanism that produces unequal outcomes, as much as it is a key resource in contesting existing inequalities. Participants in the growing transnational movement for tax justice (Tax Justice Network, n.d.) operate with a powerful historical narrative - a story about how high wealth taxes do not stifle economic growth, backed up with substantial evidence from the mid-20th century - that effectively contradicts and supplants the hegemonic neoliberal politics of memory.

Relatedly, the study of social milieus (Vester 2003) provides a window into class and memory. Maurice Halbwachs had already suggested so in his essay entitled Social Classes and their Traditions (1992, 120-166). Halbwachs was concerned with the sedimentation of memory in the (inter)personal realm, a space that, as he saw it, remained sheltered from constant change. He asserted that deeply held beliefs and shared orientations in private spaces - especially the "concerns of the family" (ibid., 141) were more persistent, and socially more consequential, than the technical expertise traded in the domain of work and professional 
identity. It remains a key insight today: Shared memories and traditions that animate the sense of self are mutually affirmed in bonds of loyalty. A contemporary application of Halbwachs' propositions could lead us to examine cultural meaning in the formation, maintenance, and breaking, of social network ties in contexts marked by economic inequality.

Another approach to social milieus is offered by Pierre Bourdieu (1984), who conceptualizes them in terms of fields and relations. From the perspective of memory activism, Bourdieu's work raises the important question of what the cultural determinants of cross-class alliances between various milieus might look like. Sociologists know that social movements thrive when they are supported and reinforced by networks that effectively link different segments of society. Such constellations provide manifold resources, but also allow a diversity of goals and styles to prevail. The mechanism of cultural differentiation described by Bourdieu might be a serious obstacle for the formation of cross-cutting ties in some cases, but perhaps less so in others.

As noted, memory scholars also have much to gain from research on working class milieus in social history and labor studies (Berger 2017, Jones 2012). As global economies are undergoing significant transformations, milieu-specific structures of feeling are recalibrated in processes of deindustrialization, the growing significance of service sector and precarious labor, as well as automation and digitization. A key insight from case studies in this area is that working class and precarious milieus are never merely acquiescent or fatalistic about the decline of the availability and the quality of jobs, financialization, and political exclusion, but that instead, a range of more or less outspoken strategies of resistance, noncompliance, and contestation can be found. Shared stories and - often gendered - narratives about one's trajectory in society are decisive in sustaining practices of defiance. Already, Paul Willis (1977) formulated this insight in his classic Learning to Labor: How Working Class Kids Get Working Class Jobs. It remains a central task to understand how people construe a sense of what is possible; to apprehend what cultural scripts and narratives, as well as what 
person or social network embodying and spreading these ideas, equips them with a sense of agency. Survey research suggests that globally, economically vulnerable populations are everywhere more critical of inequality than those in higher status positions (Bottero 2019, 2829).

\section{Ethnicity, race and gender}

Members of minorities and, in particular, racially stigmatized and excluded groups are systematically deprived of both material resources and recognition in society. Globally, minorities and racialized groups often have less access to valuable and well-paying jobs, and they regularly lack the means to accumulate wealth. As a consequence, in these communities, structural disadvantage is regularly transmitted from one generation to the next. Memory, as a practice of cultural self-assertion and knowledge about one's history, suffers everywhere where time is in short supply (because of the need to care for the necessities of everyday life), or worse even, where poverty prevails.

The example of social movements fighting for racial justice in the United States (Eyerman 2001, Hannah-Jones and Elliot 2019), illustrates just how closely economics and memory activism are intertwined. Slavery was a system of both political and economic domination. The institutional suppression of African Americans' claims to equality (the 19th century, post-civil war promise that any freed slave would receive 40 acres and a mule never materialized; instead, new forms of labor market discrimination were put in place in the Jim Crow era and beyond) has persisted for generations. Today, African American families still own merely a small fraction of the wealth of a typical white American household and are much more likely to experience social downward mobility. Activists promoting racial justice in the US today arguably advance a mnemonic discourse of transitional justice, despite the absence of regime change (see Araujo this volume). In a global perspective, memory scholars 
are called upon to study comparatively how racially stigmatized groups employ memory narratives differently to cope with discrimination-as-dispossession.

Finally, memory scholars are increasingly paying attention to the links between gender and class (Reading 2019). From comparative welfare research, we know that the life-long economic penalties of motherhood vary according to normative images about the family that are baked into social policy schemes. In economies characterized by a gendered division of labor, history-writing is part of the production of "mnemonic capital" (ibid., 301). As a cultural discourse about the economy, gender is deeply enmeshed with the fateful binary of productive and non-productive labor in society. Memory activists, in the way they conceive of the economy, move beyond the semiotically charged domain of industrial, male labor and to turn attention to sectors such as health and child care, each, potentially, with their own milieubased grammars of discontent and potentials for mobilization. Memory scholars and activists can also contribute to our understanding of misogyny and reactionary attacks on gender equality: They unveil anti-feminist and homophobic discourse in the ways in which it draws on historical images to invoke a mythological duty to restore a natural household economy.

From this brief overview, it becomes clear that the relation between memory activism and class is not directly apparent, but that efforts to think them together may well provide an integrative perspective on the somewhat elusive category of class, one that allows to identify similar experiences and perceptions of inequality not just within, but also across social groups and thus to ask for systematic variation and contingency over time. It seems promising to synthesize working class and precariat memories of dispossession and misrecognition into a more comprehensive theoretical perspective on the "political economy of memory" (Allen 2016), while acknowledging that some milieus in society are more open to social change than others (Vester 2003). By demonstrating that inequality is not a personal but a collective problem, historically minded memory activists can tackle the stigma, and the silencing of class, that is itself an outcome of the class structure of global society. 


\section{References}

Alexander, Jeffrey C. 2018. "The Societalization of Social Problems: Church Pedophilia, Phone Hacking, and the Financial Crisis." American Sociological Review 83, no. 6: 1049-1078.

Allen, Matthew J. 2016. "The Poverty of Memory: For Political Economy in Memory Studies." Memory Studies 9, no. 4: 371-375.

Arnold, Thomas C. 2001. "Rethinking Moral Economy." American Political Science Review 95, no. $1,85-95$.

Bartha, Eszter. 2013. Alienating Labour: Workers on the Road from Socialism to Capitalism in East Germany and Hungary. New York: Berghahn Books.

Berger, Stefan. 2017. "Labour Movements in Global Historical Perspective: Conceptual Eurocentrism and its Problems." In The History of Social Movements in a Global Perspective, edited by Stefan Berger and Holger Nehring, 385-418. New York: Palgrave MacMillan.

Bottero, Wendy. 2019. A Sense of Inequality. London: Rowman \& Littlefield International.

Bourdieu, Pierre. 1984. Distinction: A Social Critique of the Judgement of Taste. Cambridge: Harvard University Press.

Eribon, Didier. 2013. Returning to Reims. Los Angeles: MIT Press.

Esping-Anderson, Gøsta. 1990. The Three Worlds of Welfare Capitalism. London: Polity Press.

Eyerman, Ron. 2001. Cultural Trauma: Slavery and the Formation of African American Identity. New York: Cambridge University Press.

Halbwachs, Maurice. 1992. On Collective Memory. Chicago: University of Chicago Press.

Jones, Ben. 2012. The Working Class in Mid-twentieth-century England: Community, Identity and Social Memory. Manchester: Manchester University Press.

Knight, Daniel M. 2012. "Cultural Proximity: Crisis, Time and Social memory in Central Greece." History and Anthropology 23, no.3: 349-374.

Lyall, Angus. 2018. "A Moral Economy of Oil: Corruption Narratives and Oil Elites in Ecuador." Culture, Theory and Critique 59, no. 4: 380-399.

Mannheim, Karl. 1972. "The problem of generations." In Essays on the Sociology of Knowledge, edited by Paul Kecskemeti, 276-322. London: Routledge \& Kegan Paul.

Ost, David. 2005. The Defeat of Solidarity. Anger and Politics in Postcommunist Europe. Ithaca: Cornell University Press.

Piketty, Thomas. 2014. Capital in the Twenty-first Century. Cambridge: Belknap Press.

Reading, Ann 2019. "The Female Memory Factory: How the Gendered Labour of Memory Creates Mnemonic Capital." European Journal of Women's Studies 26, no. 3: 293-312.

Sayer, Andrew R. 2005. The Moral Significance of Class. Cambridge: Cambridge University Press.

Thompson, Edward P. 1963. The Making of the English Working Class. New York: Vintage Books.

Todorova, Maria and Zszuza Gille, eds. 2010. Post-communist Nostalgia. New York: Berghahn Books.

Vester, Michael. 2003. "Class and Culture in Germany." Sociologia, Problemas e Práticas 42: 2564.

Willis, Paul. 1977. Learning to Labour. How Working Class Kids Get Working Class Jobs. New York: Columbia University Press.

Xu, Bin. 2019. "Intragenerational Variations in Autobiographical Memory: China's 'Sent-Down Youth' Generation." Social Psychology Quarterly 82, no. 2: 134-157.

\section{Recommended Readings:}

Hannah-Jones, Nikole and Mary N. Elliott. 2019. The 1619 Project. New York: The New York Times. 
Polanyi, Karl. 2001. The Great Transformation: The Political and Economic Origins of Our Time. Boston: Beacon Press.

Scott, James C. 1976. The Moral Economy of the Peasant: Rebellion and Subsistence in Southeast Asia. New Haven: Yale University Press.

Tax Justice Network n.d. Accessed October 9th 2020. https://www.taxjustice.net/ 